\title{
Penetration resistance in a latosol under different moisture and penetration speeds
}

\author{
Walter Francisco Molina $\mathrm{Jr}^{1}$, Sônia Maria Stefano Piedade ${ }^{2}$, Juarez Rennó Amaral ${ }^{3}$
}

\begin{abstract}
The soil penetration resistance has been used to represent the compaction situation and several authors have attempted to relate the cone index $(\mathrm{CI})$ with the bulk density. The importance of using the $\mathrm{CI}$ as source of information for decisions in agricultural activities, livestock and forestry manner, has become increasingly larger, which requires more knowledge about the penetrometers and penetrographs behavior. This study aimed to verify, in controlled laboratory conditions, the influence of soil water content and cone penetration rate to obtain the cone index, when density variation occurs. The soil was compacted by compression through a universal press cylinder which was specially designed to produce the test specimens. Bulk densities were determined from samples taken from the test specimens and their moisture content. The CI values obtained were between 0.258 and $4.776 \mathrm{MPa}$, measured in 4 moistures and 7 soil densities with 3 penetration speeds. It was concluded that the determination of IC is strongly influenced by the soil moisture but the penetration speed variation, used in this study, was not sufficient to influence the IC determination. However, the decrease in soil water content may increase the sensitiveness to detect a variation in bulk density by the use of cone index.
\end{abstract}

Key words: cone index, soil compaction, soil density.

\section{RESUMO}

\section{Resistência à penetração num Latossolo sob diferentes umidades e velocidades de penetração}

A resistência do solo à penetração tem sido muito utilizada, para representar seu estado de compactação, e vários autores têm relacionado o índice de cone (IC) com a densidade do solo. Sua importância como fonte de informações para decisões na condução das atividades agrícolas, pecuária e florestal tem-se tornado cada vez maior, o que exige mais conhecimentos a respeito do comportamento dos penetrômetros e penetrógrafos. Este estudo teve o objetivo de verificar, em condições controladas de laboratório, a influência do teor de água do solo e da velocidade de penetração do cone para a obtenção do índice de cone, quando ocorre variação da densidade. O solo foi compactado por compressão por meio de uma prensa universal dentro de um cilindro especialmente construído para produzir os corpos de prova. Foram determinadas as densidades de amostras retiradas dos corpos de prova e suas respectivas umidades. Os valores de IC obtidos situaram-se entre 0,258 e 4,776 Mpa, medidos para solos, com quatro graus de umidade e sete graus de densidade, em três velocidades de penetração. Concluiu-se que a determinação do IC é fortemente influenciada pela umidade do solo, o que não ocorreu com a variação da velocidade de penetração, nos limites do estudo. No entanto, a diminuição do teor de água do solo pode aumentar a sensibilidade, na detecção da variação da densidade pelo uso do índice de cone.

Palavras-chave: índice de cone, densidade do solo, compactação.

${ }^{1}$ Agronomist engineer, Doctor of Science. Departamento de Engenharia de Biossistemas, Escola Superior de Agricultura "Luiz de Queiroz", Avenida Pádua Dias, 11, 13418-900, Piracicaba, São Paulo, Brasil. wfmolina@usp.br (corresponding author).

${ }^{2}$ Agronomist engineer, Doctor of Science. Departamento de Ciências Exatas, Escola Superior de Agricultura "Luiz de Queiroz", Avenida Pádua Dias, 11, 13418-900, Piracicaba, São Paulo, Brasil. soniamsp@usp.br

${ }^{3}$ Eletronic engineer, Master of Science. Departamento de Engenharia de Biossistemas, Escola Superior de Agricultura "Luiz de Queiroz", Avenida Pádua Dias, 11, 13418-900, Piracicaba, São Paulo, Brasil. jramaral@usp.br 


\section{INTRODUCTION}

The cone index achievement, resulting from resistance measurement offered to the soil by the penetration of a metal cone in the profile, is one expedite method to characterize its physical state. The resulting parameter from this determination is often correlated with the mechanical impedance for roots' development, or so with the degree of compaction or soil density, as well as, with the changes in this parameter, caused by the traffic of machines and equipments, with the traction capacity prediction and the results of operations performed by agricultural implements, among other uses.

The interest in cone index measurement was considerably increased with the acreage developing under no tillage system, where there is the compaction increase of the soil surface layers and its consequential interference in the agricultural productivity. However, the information about the negative effects of soil compaction in crop productivity, under field conditions, are scarce, as a result of the difficulty in isolating the factor soil compaction (Secco et al. 2004). These authors concluded that densities up to $1.51 \mathrm{~g} \mathrm{~cm}^{-3}$ and penetration resistance of $2.6 \mathrm{MPa}$ did not affect soybean yield. Working in different soil conditions, variety and moisture, Beutler \& Centurion (2004) found productivity decrease (also for soybean) from penetration resistance with superior values than $0.85 \mathrm{MPa}$. Freddi et al. (2009) affirm that both increases, the bulk density and the penetration resistance, influenced negatively in corn yield, even as top values of root growth were at intermediate levels between the highest and lowest penetration resistance values obtained in the study.

With the objective of evaluating the traffic effects of tires with different tread construction characteristics (radial or diagonal) and the applied loads on the soil, Nagaoka et al. (2003) used cone penetrometers, concluding that the increasing of load applied, causes an increment on penetration resistance, and this fact is credited to the bulk density increase. It was also detected the effect due to different types of tire construction. Fernandes et al. (2008) identified areas where the cone penetration resistance in soil is influenced by the traffic of forest harvesting equipment.

Studying the moisture influence in resistance to penetration, Assis et al. (2009) concluded that the relations are reversed. Major changes were observed in the cone index for small moisture variations and higher degrees of resistance in clay soils than in sand soils. Furthermore, Molin et al. (2006) comment that the soil moisture largely affected by its clay content, is one of the factors that influences the values of cone index measured by penetrometers. Cunha et al. (2002) showed similar conclusions, adding the fact that compaction amount also increases cone index values. Lima et al. (2007) states that different penetration resistance values occur when soil moisture varies, with $2 \mathrm{MPa}$ cone index may represent densities from 1.44 to $1.76 \mathrm{~g} \mathrm{~cm}^{-3}$, and the $3 \mathrm{MPa}$ cone index could be relative to the range of 1.53 to $1.88 \mathrm{~g} \mathrm{~cm}^{-3}$.

However, Sojka et al. (2001) reported that, besides the use of instruments to measure the cone penetration into the soil is very common as a physical characterization method, such determinations are rarely followed by another information that allows to quantify how obtained cone index values are influenced by other parameters related with physical properties of each soil. Moreover, as found by Beutler et al. (2007), different equipments can produce distinct results under the same conditions, although indicate equivalent tendencies. The authors noticed that these results are related with devices construction characteristics, even though the cone used in the measurements were standardized.

Using distinct geometry cones, Sudduth et al. (2004) observed different penetration resistance values, in equivalent soil conditions. The same tests were repeated for varied penetration speeds, and no differences were observed between the equipment responses. In addition, Fritton (1990) observed that laboratory tests had shown that the average variation of speed penetration of a cone in soil may result in $11 \%$ cone index values variation. ASAE (2003) recommends that cone penetration rate should be $30 \mathrm{~mm} \mathrm{~s}^{-1}$ and suggests that for hard or firm soil, which is impossible to maintain this speed, small variations to less would not result in significant errors. Despite many authors' affirmations about the influence of cone penetration speed of the penetrometers, Oliveira et al. (2011) affirm that many tests are still necessary, in order to obtain more details about the soil-penetrometer interaction at penetration variable rates.

Therefore, this study aimed to verify, in controlled laboratory conditions, the influence of the soil water content and the cone penetration rate, to obtain the cone index, when density variation occurs.

\section{MATERIALS AND METHODS}

The granulometric composition of the soil used in the tests consisted of $438 \mathrm{~g} \mathrm{~kg}^{-1}$ clay, $151 \mathrm{~g} \mathrm{~kg}^{-1}$ silt and $411 \mathrm{~g}$ $\mathrm{kg}^{-1}$ sand and were classified, according to Embrapa (2009), as eutroferric red latosol, clay texture. The water content and the bulk density were obtained in each test, according to Embrapa (1997).

Soil samples were collected and scattered in a black plastic film, for air drying. After that, were sieved through a $4 \mathrm{~mm}$ mesh sieve, again distributed over the black plastic film, in a uniform layer with a thickness of approximately $50 \mathrm{~mm}$, moistened with water, gradually sprayed by a costal 
sprayer, until an approximate saturation condition was observed. With the purpose of homogenizing the water content, the material was exposed to the weather for three days, and at the end of this time, was divided into four equal volume parts. One of then was immediately wrapped in polyethylene plastic bags, in order to preserve its water content. The other three parts kept exposed to the air, in shade, so that, upon evaporation, the water content variation was obtained. Every two days, each of the remaining parts was also wrapped in plastic bags.

The penetration resistance tests were performed on artificially compacted soil specimens. To obtain these specimens, devices were constructed, from metal cylinders, with $0.4 \mathrm{~m}$ length and $0.16 \mathrm{~m}$ internal diameter. The cylinders were lengthwise divided, and these halves were joined together by hinges, to allow its opening, as shown in Figure 1. Diametrically opposed flanges were used to keep the device closed, during the compression of the soil deposited inside.

The experiment was conducted in a completely randomized design, with four moisture levels and three cone penetration speeds. Preliminary tests determined that, due to the standard deviation observed for the compacted soil density obtained, each procedure must be repeated four times. Furthermore, it was observed that at the end of each compression was necessary that the press used remained static for at least $600 \mathrm{~s}$ until the compression stress was stabilized in each layer, with no volume change. Figure 2 shows the soil behavior for a certain compressive layer, which refers to the volume variation and subsequent stress stabilization.

Soil compaction was performed according to ABNT NBR 7182 (1986), adapted to the use of universal tensile and compression equipment Instron ${ }^{\mathrm{TM}}$, model 4466. The soil was placed on the cylinder, in layers, with a volume of $4.98 \mathrm{dm}^{3}$ each. As the soil of each layer was added into the

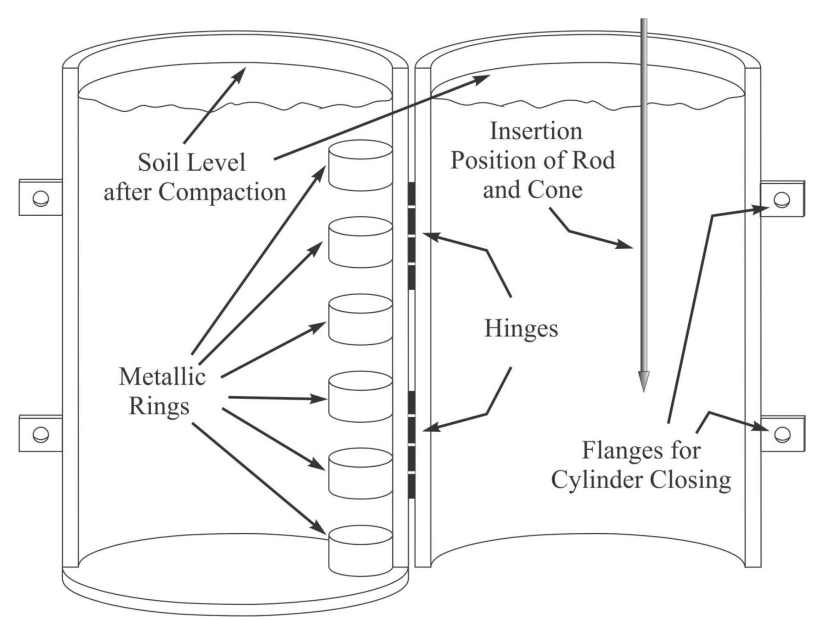

Figure 1. Schematic cylindrical device built for soil compression and test of specimens production. cylinders, metal rings were laterally placed, whose objective was to obtain samples to determine soil density and water content and, subsequently, correlate with cone index observed at that position (see Figure 2). The maximum $^{4}$ stresses the soil was exposed to promote the different densities were $98.1 \mathrm{kPa}, 196.1 \mathrm{kPa}, 294.2 \mathrm{kPa}$ and $392.3 \mathrm{kPa}$. After each layer addition, a metal plate with the same cross-sectional shape of the compaction device was placed over the soil portion, to its compression by vertical displacement, at a constant speed of $0.33 \mathrm{~mm} \mathrm{~s}^{-1}$. Before adding a new layer of soil, the previous layer surface was scarified, and the process was repeated, until the distance between the cylinder upper edge and the soil therein was fewer than the corresponding value of two rings samplers' heights. In this case, the cylinder volume was completed to its maximum, and the final compression proceeded, forming the specimen.

The soil penetration resistance was determined using ASAE standard cone (1999), in three speeds levels: V1 = $2.83 \mathrm{~mm} \mathrm{~s}^{-1}, \mathrm{~V} 2=5.67 \mathrm{~mm} \mathrm{~s}^{-1}$ and V3 $=8.47 \mathrm{~mm} \mathrm{~s}^{-1}$. The rod which supports the cone was adapted to the press used to compress the specimen, whose load cell recorded, with $5 \mathrm{~mm}$ intervals, the cone displacement and the correspondent force to penetration resistance. The first $25 \mathrm{~mm}$ readings, corresponding to the cone height, were discarded.

After each determination, the cylinders were opened for removing the metal rings from its inside position, being determined each metal ring position in relation to the device bottom. The rings were thinned at both ends, and the collected soil from its inside were transferred to aluminum caps and forwarded to oven drying for moisture and density determination.

The statistical analysis were performed based on different repetitions numbers. It was considered repetition the values pairs that make correspondence between the cone index and soil density, founded in each metal ring placed inside the cylinders. The measurements produced more than ten thousand pairs of points, which were divided into seven density classes. The objective was to determine an average for the soil density value, which the variation coefficient was less than $4 \%$. At first, the variance analysis F-test was applied and, subsequently, the cone index average, for each speed of penetration, were compared by Tukey test.

\section{RESULTS AND DISCUSSION}

Moisture conditions where the soil was worked and the bulk density obtained, after the compression process, are shown in Table 1.

\footnotetext{
${ }^{4}$ Equivalent variations stress between 1 and $4 \mathrm{kgf} \mathrm{cm}^{-2}$
} 
The compaction process did not produced uniform density soil blocks at specimens and, when the water content was higher than $0.2 \mathrm{~kg} \mathrm{~kg}^{-1}$ (U1 and U2), it was difficult to obtain bulk densities with lower values (1.11 and $1.21 \mathrm{~g} \mathrm{~cm}^{-3}$ ), while when the water content was less than $0.2 \mathrm{~kg} \mathrm{~kg}^{-1}$ (U3, U4), higher values of density were not obtained. Probably, soil particles are better accommodated in the presence of water, resulting in higher bulk density, even with lower compressive loads. Bulk density variation occurred, within each sample, in every determination, mainly in the transition region between compacted layers, successively, which was satisfactorily found by the introduction of metal rings in the cylinders.

Regardless the cone penetration speed (Table 2), it was observed that as the soil moisture decreases, the cone index values increase with increasing of bulk density, which agrees with the results of Lima et al. (2007). However, as the bulk density values decrease, there is a difficulty in correlating its variation with the corresponding value obtained for the cone index, which is evident in the case of higher moisture levels (U1, U2). In U4 moisture content, the cone index was able to detect changes in soil density, for all levels.
Working with dystrophic latosol confined in PVC tubes, which the texture is similar to the soil texture used for this test, Beutler et al. (2007) concluded that there is a correlation between the cone index values obtained by penetrometers, and bulk density. The authors used the specimens with three levels of compactation (soil densities equal to $1.17,1.41$ and $1.58 \mathrm{~g} \mathrm{~cm}^{-3}$ to a water content of $0.12 \mathrm{~kg} \mathrm{~kg}^{-1}$ to $0.93 ; 1.15$ and $1.27 \mathrm{~g} \mathrm{~cm}^{-3}$ to a water content of $0.27 \mathrm{~kg} \mathrm{~kg}^{-1}$ ) and three replications. When these results were compared with the present study results, it was observed that they agreed with those obtained for moisture U4 (0.12 $\left.\mathrm{kg} \mathrm{kg}^{-1}\right)$, but it was impossible to compare the results obtained for moisture U1 $\left(0.264 \mathrm{~kg} \mathrm{~kg}^{-1}\right)$, because in this case, corresponding values of bulk density were not obtained to allow the comparison. Nevertheless, the trend observed in Table 2 shows that the bulk density values lower than $1.50 \mathrm{~g} \mathrm{~cm}^{-3}$, for moisture U1, doesn't show significant statistics differences.

Figure 3 shows the results obtained for cone index values, for different density and soil moisture degrees. These results indicate that cone index values are influenced by the soil water content, which agrees with the information of Molin et al (2006).

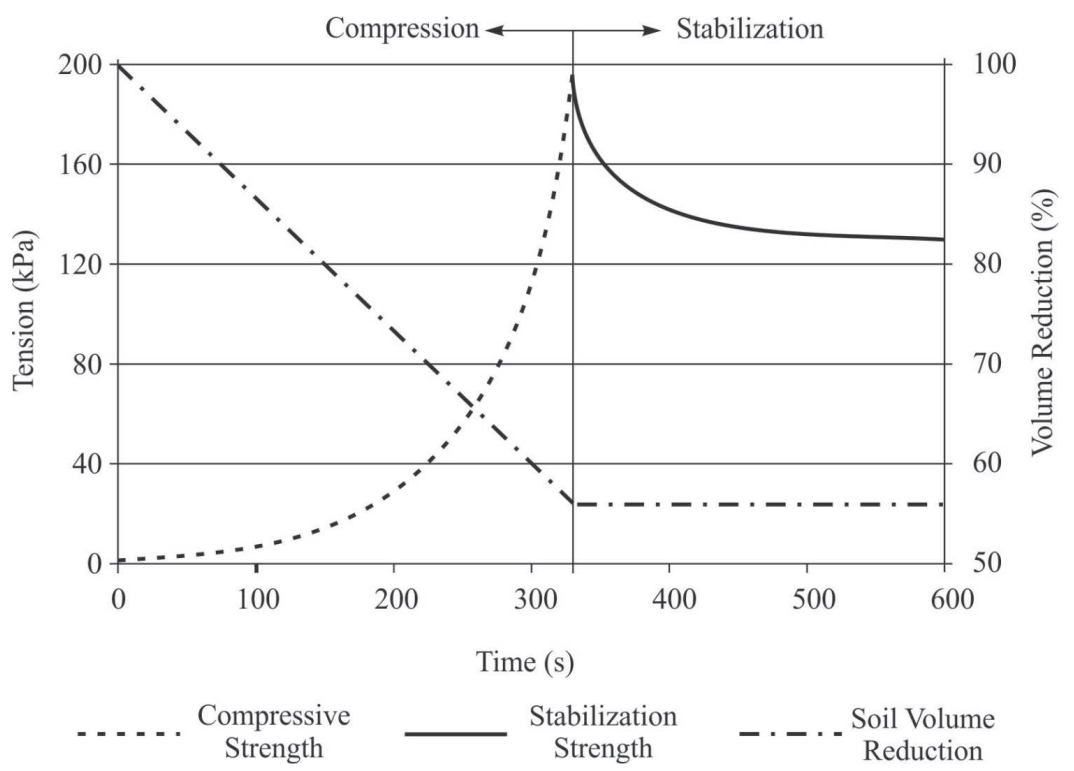

Figure 2. Stress variation during the soil compression process and its response during the stabilization period, when the press stopped the dislocation by the force at the maximum, for which it was scheduled $(3.842 \mathrm{kN})$, with soil water content of $0.224 \mathrm{~kg} \mathrm{~kg}^{-1}$.

Table 1. Water contents (U1 to U4) and bulk density (Ds, 1-7) and their respective variation coefficients (cv), obtained from the analysisof the collected material from the rings included in the specimens

\begin{tabular}{|c|c|c|c|c|c|c|c|c|}
\hline & & 1 & 2 & 3 & 4 & 5 & 6 & 7 \\
\hline Soil water contents* & & 0.264 & 0.224 & 0.187 & 0.120 & $-x^{-}$ & $-\mathrm{X}^{-}$ & $-x-$ \\
\hline$\left(\mathrm{kg} \mathrm{kg}^{-1}\right)$ & $\mathrm{cv}$ & 4.71 & 4.72 & 3.51 & 7.14 & $-\mathrm{x}-$ & $-\mathrm{X}-$ & $-x-$ \\
\hline SoilDensity & & 1.11 & 1.21 & 1.30 & 1.41 & 1.50 & 1.61 & 1.70 \\
\hline$\left(\mathrm{g} \mathrm{cm}^{-3}\right)$ & $\mathrm{cv}$ & 2.57 & 2.65 & 2.08 & 1.96 & 1.92 & 1.79 & 2.00 \\
\hline
\end{tabular}

*In Table 2 the water contents are associated with capital letters $\mathrm{U}$, followed by numbers 1 to 4.

Rev. Ceres, Viçosa, v. 60, n.5, p. 715-721, set/out, 2013 
For the same soil density values, it is observed that the cone index values increase with the decrement of soil water content, in agreement with Busscher et al. (1997), Cunha et al. (2002), Tormena et al. (2002) and Watanabe et al. (2002), except for values under $1.21 \mathrm{~g} \mathrm{~cm}^{-3}$, in moisture $\mathrm{U} 4$, for the same values, in U3. This fact can be explained because, by removing the disk used on the cylinder to subordinate the soil to compression when the specimens were compacted, it was noticed that the surface was not aggregated enough (loose soil), a fact that was characterized in the last layer. Even ignoring the first 25 $\mathrm{mm}$ on the specimens surface readings, and as the soil was still loose in the surface layer, it was resulted from this, penetration resistance lower values.

The soil moisture was determinant in the results' behaviour (Figure 4), because, for soil water content higher than $0.187 \mathrm{~kg} \mathrm{~kg}^{-1}(\mathrm{U} 3)$, the cone penetration speed variation didn't show a conclusive tendency to the middle in the result, while for the lower moisture (U4 $\left.=0.120 \mathrm{~kg} \mathrm{~kg}^{-1}\right)$, the results were antagonistic, with the bulk density increase.

Table 2. Statistical analysis of cone index (MPa) values, obtained when comparing the bulk density $\left(\mathrm{g} \mathrm{cm}^{-3}\right)$ for each speed $(\mathrm{V})$ at each moisture level (U)

\begin{tabular}{lcccccc}
\hline Ds & U1V1 & U1V2 & U1V3 & U2V1 & U2V2 & U2V3 \\
\hline 1.11 & $-\mathrm{x}-$ & $-\mathrm{x}-$ & $-\mathrm{x}-$ & $-\mathrm{x}-$ & $-\mathrm{x}-$ & $-\mathrm{x}-$ \\
1.21 & $-\mathrm{x}-$ & $-\mathrm{x}-$ & $-\mathrm{x}-$ & $0.798 \mathrm{c}$ & $0.842 \mathrm{c}$ & $0.880 \mathrm{c}$ \\
1.30 & $0.258 \mathrm{~d}$ & $0.329 \mathrm{~d}$ & $0.332 \mathrm{c}$ & $0.818 \mathrm{c}$ & $0.786 \mathrm{c}$ & $0.873 \mathrm{c}$ \\
1.41 & $0.364 \mathrm{~cd}$ & $0.370 \mathrm{~d}$ & $0.412 \mathrm{c}$ & $0.859 \mathrm{c}$ & $0.863 \mathrm{c}$ & $0.959 \mathrm{c}$ \\
1.50 & $0.472 \mathrm{c}$ & $0.527 \mathrm{c}$ & $0.475 \mathrm{c}$ & $0.934 \mathrm{c}$ & $0.982 \mathrm{c}$ & $1.080 \mathrm{c}$ \\
1.61 & $0.766 \mathrm{~b}$ & $0.864 \mathrm{~b}$ & $0.934 \mathrm{~b}$ & $1.275 \mathrm{~b}$ & $1.331 \mathrm{~b}$ & $1.698 \mathrm{~b}$ \\
1.70 & $1.024 \mathrm{a}$ & $1.470 \mathrm{a}$ & $1.521 \mathrm{a}$ & $2.054 \mathrm{a}$ & $2.118 \mathrm{a}$ & $2.163 \mathrm{a}$ \\
\hline $\mathbf{D s}$ & $\mathbf{U 3 V 1}$ & $\mathbf{U 3 V 2}$ & $\mathbf{U 3 V 3}$ & $\mathbf{U 4 V 1}$ & $\mathbf{U 4 V 2}$ & $\mathbf{U 4 V 3}$ \\
\hline 1.11 & $1.087 \mathrm{~d}$ & $1.158 \mathrm{~d}$ & $1.116 \mathrm{~d}$ & $0.572 \mathrm{~d}$ & $0.599 \mathrm{~d}$ & $0.857 \mathrm{~d}$ \\
1.21 & $1.276 \mathrm{~d}$ & $1.272 \mathrm{~d}$ & $1.243 \mathrm{~d}$ & $1.846 \mathrm{c}$ & $1.824 \mathrm{c}$ & $2.018 \mathrm{c}$ \\
1.30 & $1.581 \mathrm{c}$ & $1.645 \mathrm{c}$ & $1.628 \mathrm{c}$ & $3.267 \mathrm{~b}$ & $2.947 \mathrm{~b}$ & $2.828 \mathrm{~b}$ \\
1.41 & $2.670 \mathrm{~b}$ & $2.663 \mathrm{~b}$ & $2.730 \mathrm{~b}$ & $4.276 \mathrm{a}$ & $3.808 \mathrm{a}$ & $3.840 \mathrm{a}$ \\
1.50 & $3.135 \mathrm{a}$ & $3.189 \mathrm{a}$ & $3.126 \mathrm{a}$ & $-\mathrm{x}-$ & $-\mathrm{x}-$ & $-\mathrm{x}-$ \\
1.61 & $3.449 \mathrm{a}$ & $3.327 \mathrm{a}$ & $3.170 \mathrm{a}$ & $-\mathrm{x}-$ & $-\mathrm{x}-$ & $-\mathrm{x}-$ \\
1.70 & $-\mathrm{x}-$ & $-\mathrm{x}-$ & $-\mathrm{x}-$ & $-\mathrm{x}-$ & $-\mathrm{x}-$ & $-\mathrm{x}-$ \\
\hline
\end{tabular}

*In columns, same letters indicate equal values at Tukey test, with statistical significance at $5 \%$ probability. For lower moisture, it was difficult to obtain bulk density higher values, probably because of water lubrication action. The opposite occurred for high moisture, where the material were more easily compacted by the load.

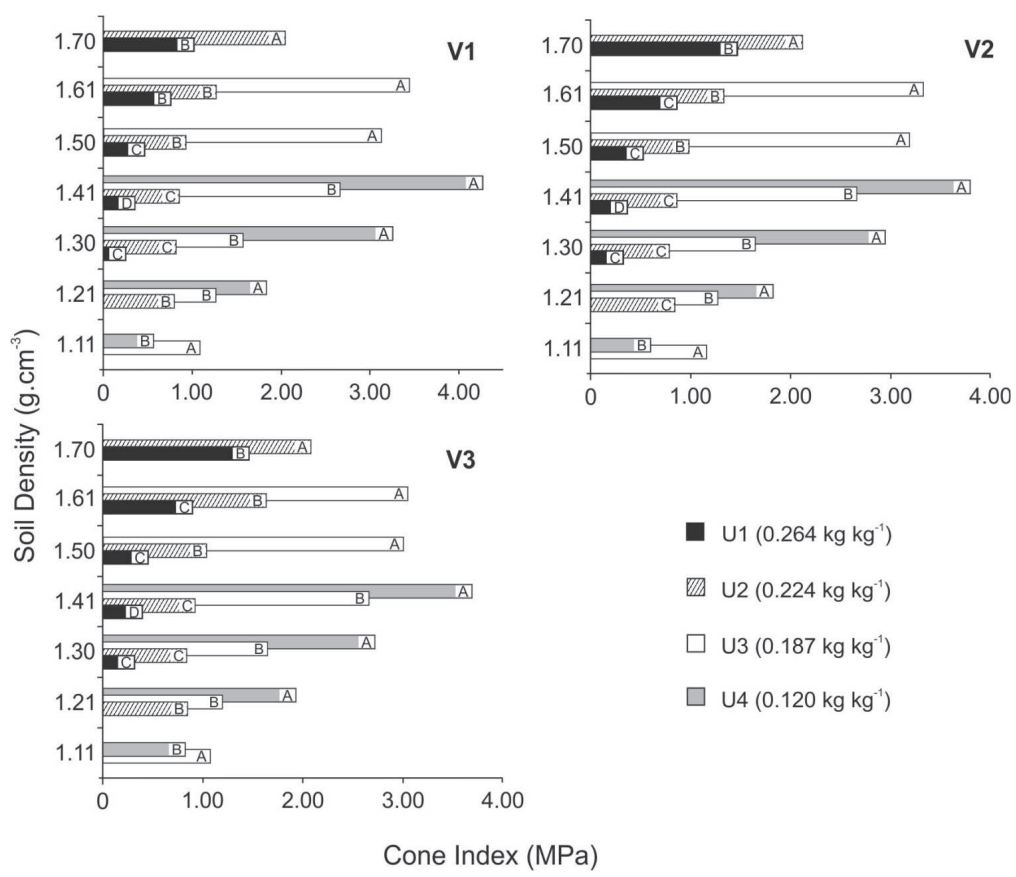

Figure 3. Influence of water content on the cone index variation, according to thebulk density, in each studied speed. Equal letters represent equal amounts at $5 \%$ probability values of cone index byTukey test. 


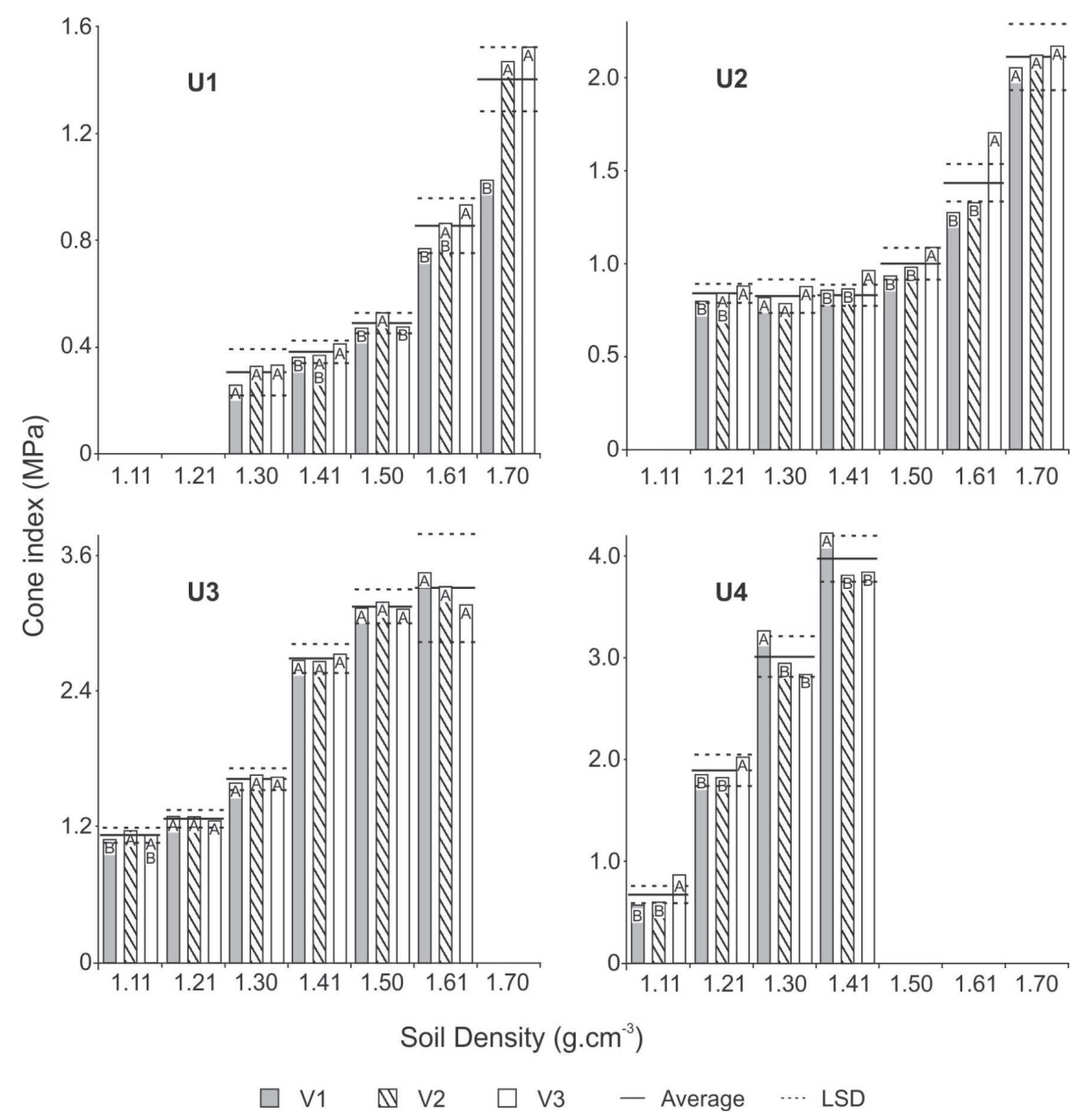

Figura 4. Cone index variation, its respectives average and least significant difference (LSD). Equal letters represent equal amounts at $5 \%$ probability for each bulk density, in its respective moisture, in function of speed variation, by Tukey test.

In this case, lower bulk densities produced higher cone index values, in higher speeds, inverting the result from $1.21 \mathrm{~g} \mathrm{~cm}^{-3}$, while the lower speeds produced higher values.

The results showed that, in contrast to Fritton (1990) assertions, it was impossible to generalize penetration speeds effects by varying the cone index values, since statistical analysis results do not indicate a standardized behavior, which agrees with Oliveira et al. (2011) conclusions. The results, however, suggest that higher moisture content (U1 and U2), influence on cone index speed, especially when the bulk density increase, disagreeing with Sudduth et al. (2004) and ASAE (2003) assertions. In this study, the variation from $3 \mathrm{~mm} \mathrm{~s}^{-1}$ (10\% relative value as the established standard in the cone index determinations) in the speed penetration was sufficient to cause differences on results.

\section{CONCLUSIONS}

The cone index determination is strongly influenced by soil moisture and, it is necessary that, when using this parameter as characteristic or physical soil property, the values be supplemented by the information of which moisture they were obtained.

The speed penetration variation of the cone into the soil, in the studied limits, was not sufficient to influence, decisively, the cone index values. However, some tendencies suggest that, for higher levels of water in soil, higher penetration speeds may change the readings, with the increase of bulk density.

The reduction of soil water content may increase the cone index sensitiveness to detect bulk density variations. However, more studies are necessary to confirm this statement.

\section{REFERENCES}

ABNT Associação Brasileira de Normas Técnicas (1986) NBR 7182: Solo - ensaio de compactação. Rio de Janeiro. 10p.

ASAE American Society of Agricultural Engineers (1999) ASAE S313.1: Soil cone penetrometer. In: ASAE Standards 1999: standards engineering practices data, 46th ed. Saint Joseph. p.859-860. 
ASAE - American Society of Agricultural Engineers (2003) ASAE EP542: Procedures for Using and Reporting Data Obtained with the Soil Cone Penetrometer. In: ASAE Standards 2003: standards engineering practices data. $46^{\text {th }}$ ed. Saint Joseph, ASAE. p.10081011 .

Assis RL, Lazarini GD, Lanças KP \& Cargnelutti Filho A (2009) Avaliação da resistência do solo à penetração em diferentes solos com a variação do teor de água. Engenharia Agrícola, $29: 558-568$

Beutler NA \& Centurion JF (2004) Compactação do solo no desenvolvimento radicular e na produtividade da soja. Pesquisa Agropecuária Brasileira, 39:581-588.

Beutler NA, Centurion JF \& Silva AP (2007) Comparação de penetrômetros na avaliação da compactação de latossolos. Engenharia Agrícola, 27:146-151.

Busscher WJ, Bauer PJ, Camp CR \& Sojka RE (1997) Correction of cone index for soil water content differences in a coastal plain soil. Soil \& Tillage Research, 43:205-217.

Cunha JPAR, Vieira LB \& Magalhães AC (2002) Resistência mecânica do solo à penetração sob diferentes densidades e teores de água. Engenharia na Agricultura, 10:01-07.

Embrapa - Empresa Brasileira de Pesquisa Agropecuária (1997) Serviço Nacional de Levantamento e Conservação dos Solos. Manual de métodos de análise de solo. $2^{\text {a }}$ ed., Rio de Janeiro, Embrapa. 212p.

Embrapa - Empresa Brasileira de Pesquisa Agropecuária (2009) Centro Nacional de Pesquisa de Solos. Sistema Brasileiro de Classificação de Solos. Brasília, Embrapa Solos. 366p.

Fernandes CF, Lopes SE, Modolo AJ, Silveira JCM \& Rinaldi PCN (2008) Avaliação da resistência do solo à penetração em razão de carga aplicadas pelos rodados de duas máquinas florestais e pelo arraste de madeira. Revista Ceres, 55:21-27.

Freddi OS, Centurion JF \& Almeida CX (2009) Compactação de um latossolo vermelho de textura argilosa afetando o sistema radicular e a produtividade do milho. Revista Ceres, 56:654665
Fritton DD (1990) A standard for interpreting soil penetrometer measurements. Soil Science, 150:542-551.

Lima CLR, Reichert JM, Reinert DJ, Suzuki LEAS \& Dalbianco L (2007) Densidade crítica ao crescimento de plantas considerando água disponível e resistência à penetração de um Argissolo Vermelho distrófico arênico. Ciência Rural, 37:1166-1169.

Molin JP, Magalhães RP \& Faulin GDC (2006) Análise espacial da ocorrência do índice de cone em área sob semeadura direta e sua relação com fatores do solo. Engenharia Agrícola, 26:442-452.

Nagaoka AK, Lanças KP, Castro Neto P, Lopes A \& Guerra SPS (2003) Resistência do solo à penetração, após o tráfego com dois tipos de pneus utilizando-se um equipamento para ensaio dinâmico. Revista Brasileira de Engenharia Agrícola e Ambiental, 7:387-393.

Oliveira RMS, Almeida MSS, Motta HPG \& Almeida MCF (2011) Influence of Penetration Rate on Penetrometer Resistance. Journal of Geotechnical and Geoenvironmental Engineering, 7:695-703.

Sojka RE, Busscher WJ \& Lehrsch GA (2001) In situ strength bulk density, and water content relationship of a durinodic xeric haplocalcid soil. Soil Science, 166:520-529.

Secco D, Reinert DJ, Reichert JM \& Da Roz CO (2004) Produtividade de soja e propriedades físicas de um latossolo submetido a sistemas de manejo e compactação. Revista Brasileira de Ciência do Solo, 28:797-804.

Sudduth KA, Hummel JW \& Drummond ST (2004) Comparison of the Veris Profiler 3000 to an ASAE standard penetrometer Applied Engineering in Agriculture (Technical Note ASAE), 20:535-541.

Tormena CA, Barbosa MC, Costa ACS \& Gonçalves ACA (2002) Densidade, porosidade e resistência à penetração em Latossolo cultivado sob diferentes sistemas de preparo do solo. Scientia. Agricolae, 59:795-801.

Watanabe SH, Tormena CA, Araujo MA, Vidigal Filho PS, Pintro JC, Costa ACS \& Muniz AS (2002) Propriedades físicas de um latossolo vermelho distrófico influenciadas por sistemas de preparo do solo utilizados para implantação da cultura da mandioca. Acta Scientiarum, 24:1255-1264. 